\title{
PENGARUH PENGETAHUAN KEWIRAUSAHAAN TERHADAP SIKAP BERWIRAUSAHA SISWA SMA MUHAMMADIYAH 1 PALANGKARAYA MELALUI MINAT BERWIRAUSAHA SEBAGAI MEDIATOR
}

\author{
Oleh: Muhammad Jailani*, Chandra Anugrah Putra** dan Arif Supriyadi*** \\ E-mail: danishjayum006@gmail.com
}

\begin{abstract}
ABSTRAK
Penelitian ini bertujuan untuk memperoleh data empiris dan memastikan pengaruh signifikansi antara pengetahuan kewirausahaan dan menganalisis minat berwirausaha sebagai variabel mediasi terhadap sikap berwirausaha.Desain penelitian yang digunakan adalah desain penelitian korelasional dengan sampel sebanyak 161 orang mahasiswa yang dipilih dengan menggunakan teknik sample random sampling. Pengumpulan data menggunakan instrument kewirausahaan. Teknik analisis mediator menggunakan teknik bias corrected bootstrap method $(\mathrm{N}=5000)$ dengan confidential interval $95 \%$ pada software PROCESS. Hasil penelitian menunjukkan bahwa pengetahuan kewirausahaan secara keseluruhan berpengaruh signifikan terhadap sikap berwirausaha melalui minat berwirausaha. Simpulannya adalah bahwa pengetahuan kewirausahaan memiliki pengaruh tidak langsung yang signifikan terhadap sikap berwirausaha.
\end{abstract}

Kata Kunci: Pengetahuan Kewirausahaan, Sikap Berwirausaha Siswa, Minat Berwirausaha Sebagai Mediator

\section{ABSTRACT}

This study aims to obtain empirical data and ascertain the significance of influence between entrepreneurial knowledge and analyze entrepreneurial interest as a mediating variable on entrepreneurial attitudes. The research design used was a correlational research design with a sample of 161 students selected using random sampling techniques. Data collection uses entrepreneurial instruments. The mediator analysis technique uses a biased corrected bootstrap method $(N=5000)$ with a confidential interval of $95 \%$ on the PROCESS software. The results showed that entrepreneurship knowledge as a whole had a significant effect on entrepreneurial attitudes through entrepreneurial interest. The conclusion is that entrepreneurial knowledge has a significant indirect effect on entrepreneurial attitudes.

Keywords: Entrepreneurship Knowledge, Student Entrepreneurial Attitudes, Entrepreneurial Interest as Mediators

\section{PENDAHULUAN}

Sikap adalah kepercayaan positif atau negatif untuk menampilkan suatu perilaku tertentu. Kepercayaan-kepercayaan atau beliefs ini disebut dengan behavioral beliefs. Seorang individu akan berniat untuk menampilkan suatu perilaku tertentu ketika ia menilainya secara positif. Sikap demikian ditentukan oleh kepercayaan-kepercayaan seseorang mengenai konsekuensi dari menampilkan suatu perilaku yang dipertimbangkan berdasarkan hasil evaluasi terhadap konsekuensinya yang mungkin dia hadapi (Putra et. al.2015).

Sedangkan Wijaya (2008) menyatakan bahwa sikap terdiri dari dua aspek pokok, yaitu keyakinan individu bahwa menampilkan atau tidak menampilkan perilaku tertentu akan menghasilkan akibatakibat atau hasil-hasil tertentu, dan aspek pengetahuan individu tentang obyek sikap dapat pula berupa opini individu hal yang belum tentu sesuai dengan kenyataan; semakin positif keyakinan individu akan 
akibat dari suatu obyek sikap, maka akan semakin positif pula sikap individu terhadap obyek sikap tersebut, demikian pula sebaliknya.

Sikap berwirausaha menentukan pengetahuannya terhadap kewirausahaan. Dengan sikap yang positif maka seseorang akan cenderung untuk mencari informasi mengenai kewirausahaan. Berbeda dengan sikap negatif terhadap kewirausahaan, jika seseorang memiliki sikap negatif terhadap kewirausahaan maka akan cenderung untuk tidak mencari informasi atau bahkan mengabaikan pengetahuan mengenai kewirausahaan.

Pengetahuan

kewirausahaan

mendukung nilai-nilai wirausaha terutama bagi mahasiswa, sehingga diharapkan menumbuhkan jiwa usaha untuk berwirausaha. Sikap mandiri, motivasi dan pengetahuan kewirausahaan sangat dibutuhkan bagi mahasiswa yang berwirausaha agar mampu mengidentifikasi peluang usaha, kemudian mendayagunakan peluang usaha untuk menciptakan peluang kerja baru. Minat mahasiswa dan pengetahuan mereka tentang kewirausahaan diharapkan akan membentuk kecenderungan mereka untuk membuka usaha baru di masa mendatang. Soemanto (2002) mengatakan bahwa satu-satunya perjuangan atau cara untuk mewujudkan manusia yang mempunyai moral, sikap, dan keterampilan wirausaha adalah dengan pendidikan. Pendidikan membuat wawasan individu menjadi lebih percaya diri, bisa memilih, dan mengambil keputusan yang tepat, meningkatkan kreativitas dan inovasi, membina moral, karakter, intelektual, serta peningkatan.

Pengetahuan berwirausaha tidak didapatkan melalui informasi yang singkat semata, melainkan harus melalui sistem pembelajaran

khusus

mengenai

kewirausahaan sehingga dalam penerapannya untuk menjadi wirausahawan, para wirausahawan (enterpreneur) sudah memiliki kompetensi atau skill mengenai wirausaha dan menampilkan outcome yang baik di masyarakat. Seperti diketahui bersama bahwa pembelajaran kewirausahaan di Indonesia sudah diberikan di jenjang pendidikan Sekolah Menengah Atas. Melalui beberapa mata pelajaran-mata pelajaran, pembelajaran mengenai kewirausahaan diberikan kepada siswa SMA dengan harapan para siswa SMA akan mendapatkan pengetahuan kewirausahaan dan dapat menumbuhkan minat berwirausaha melalui sikap positif yang diajarkan di sekolah terhadap kewirausahaan.

Pengetahuan kewirausahaan dapat dimiliki oleh seseorang jika seseorang tersebut memiliki sikap positif dan minat terhadap kewirausahaan. Minat berwirausaha menurut Subandono (2007) adalah kecenderungan hati dalam diri subjek untuk tertarik menciptakan suatu usaha yang kemudian mengorganisir, mengatur, menanggung risiko dan mengembangkan usaha yang diciptakannya tersebut. Suryawan (2006) mendefinisikan minat berwirausaha adalah keinginan, ketertarikan, serta kesediaan untuk bekerja keras atau berkemauan keras untuk berdikari atau berusaha memenuhi kebutuhan hidupnya tanpa merasa takut dengan resiko yang akan terjadi serta senantiasa belajar dari kegagalan yang dialami.

Cahyaning (2014) juag berpendapat minat berwirausaha adalah keinginan dalam diri individu yang berjiwa berani menciptakan usaha agar meraih sukses untuk kehidupan yang lebih baik. Paulina (2011) Intensi berwirausaha yaitu keinginan individu melakukan tindakan wirausaha 
dengan menciptakan produk baru melalui peluang bisnis dan pengambilan risiko.

Berdasarkan definisi di atas, maka yang dimaksud dengan minat wirausaha adalah kemampuan untuk mendorong diri sendiri dan berbuat sesuatu untuk memenuhi kebutuhan hidup serta pemecahan permasalahan hidup, memajukan usaha atau menciptakan usaha baru dengan perasaan senang karena membawa manfaat bagi dirinya untuk berusaha memenuhi kebutuhan hidupnya tanpa merasa takut akan resiko yang akan dihadapi, senantiasa belajar dari kegagalan yang dialami, serta mengembangkan usaha yang diciptakannya.

Indikator minat berwirausaha menurut Menurut Purnomo (2005); 1) kemauan keras untuk mencapai tujuan dan kebutuhan hidup, 2) keyakinan kuat atas kekuatan sendiri, 3) sikap jujur dan tanggung jawab, 4) ketahanan fisik, mental, ketekunan, keuletan, bekerja dan berusaha, 5) pemikiran yang kreatif dan konstruktif, 6) berorientasi ke masa depan, dan berani mengambil resiko.

Dari penjelasan tersebut dapat dipahami bahwa minat berwirausaha tidak menutup kemungkinan menjadi salah satu fakor yang memediasi antara pengetahuan berwirausaha dengan sikap berwirausaha seseorang. Namun pada faktanya, sesuai hasil observasi awal peneliti menemukan bahwa siswa yang telah mendapatkan pengetahuan berwirausaha di sekolah menengah atas dan memiliki sikap positif terhadap wirausaha masih belum dapat menumbuhkan secara optimal minat mereka terhadap wirausaha. Hal ini bertolak belakang dengan paparan atau teori yang telah peneliti paparkan pada paragrap sebelumnya yang menyatakan bahwa minat berwirausaha memediasi pengetahuan berwirausaha seseorang terhadap sikap berwirausaha seseorang.

$$
\text { Pada observasi awal peneliti }
$$
menemukan bahwa ada sebagian siswa di SMA Muhammadiyah 1 Palangkaraya yang memiliki banyak pengetahuan mengenai berwirausaha namun mereka malah justru tidak memiliki minat untuk berwirausaha walaupun mereka mengakui bahwa mereka memiliki sikap positif terhadap kewirausahaan atau berwirausaha. Sikap positif yang mereka memiliki diwujudkan dengan berupa dukungan dan pandangan positif terhadap mereka yang menjadi wirausahawan.

Dari fenomena gap yang ditemukan peneliti di SMA Muhammadiyah 1 Palangkaraya maka peneliti merasa perlu untuk mengetahui dan menganalisis pengaruh pengetahuan berwirausaha terhadap sikap berwirausaha siswa SMA Muhammadiyah 1 Palangkaraya melalui minat berwirausaha sebagai mediator.

\section{METODE PENELITIAN}

Desain yang digunakan dalam penelitian ini adalah desain penelitian korelasional. Desain penelitian korelasional merupakan salah satu teknik analisis dalam statistik yang digunakan untuk mencari hubungan antara dua variabel yang bersifat kuantitatif. Hubungan dua variabel tersebut dapat terjadi karena adanya hubungan sebab akibat atau dapat pula terjadi karena kebetulan saja. Dua variabel dikatakan berkolerasi apabila perubahan pada variabel yang satu akan diikuti perubahan pada variabel yang lain secara teratur dengan arah yang sama (korelasi positif) atau berlawanan (korelasi negatif). 


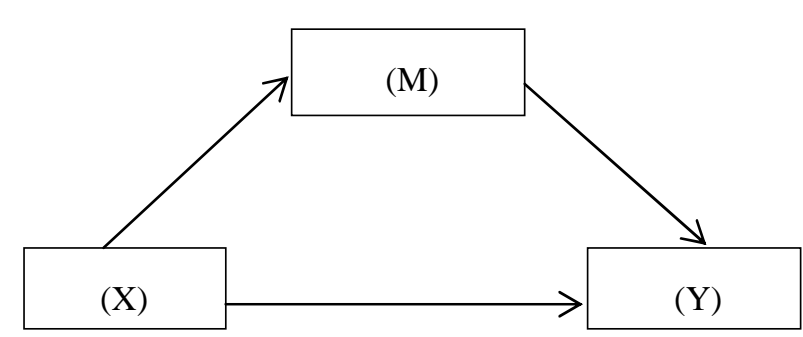

Gambar 1.

Statistical Diagram Mediator (Hayes, 2014)

Penelitian ini menggunakan pendekatan penelitian kuantitatif dengan model penelitian yang bersifat expost facto. Disebut penelitian expost facto karena peneliti berhubungan dengan variabel yang telah terjadi dan tidak perlu memberikan perlakuan terhadap variabel yang diteliti. Penelitian expost facto adalah penelitian yang mengambil atau menggali data dari peristiwa yang sudah terjadi (Wahyudin, 2015:19).

Penelitian expost facto menurut Wahyudin (2015) merupakan peneltian dimana variabel-variabel bebas telah terjadi ketika peneliti mulai dengan pengamatan variabel terikat dalam suatu penelitian. Pada penelitian ini keterikatan antar variabel bebas dengan variabel terikat telah terjadi secara alami dan peneliti dengan setting tersebut ingin melacak kembali jika dimungkinkan apa yang menjadi faktor penyebabnya. Oleh karena itu indikator capaian penelitian ini adalah 1) ingin mengetahui apakah ada pengaruh langsung antara pengetahuan berwirausaha terhadap sikap berwirausaha, 2) ingin mengetahui apakah ada pengaruh tidak langsung antara pengetahuan berwirausaha terhadap sikap berwirausaha melalui minat berwirausaha, 3) ingin mengetahui apakah ada pengaruh langsung antara minat berwirausaha terhadap sikap berwirausaha.

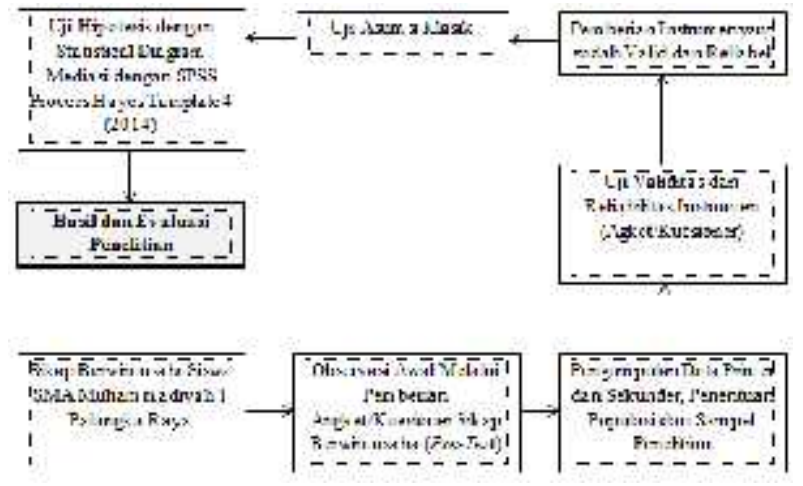

Road Map Penelitian

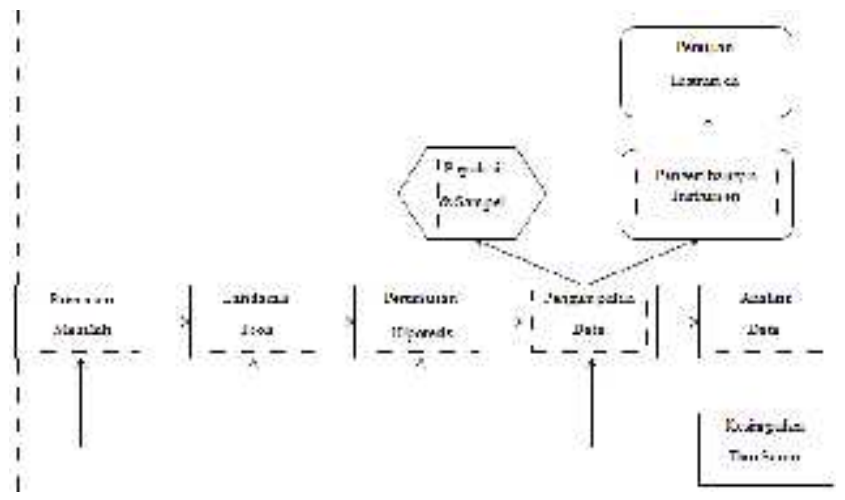

Pedoman Penelitian

Populasi dalam penelitian ini adalah semua siswa SMA Muhammadiyah 1 Palangkaraya pada jenjang kelas X, XI, dan XII. Jumlah keseluruhan populasi adalah 316 orang siswa yang berasal dari kelas lintas minat IPA dan IPS. Pengambilan sampel dalam penelitian ini menggunakan teknik Simple Random sampling, yaitu suatu tipe sampling probabilitas, dimana peneliti dalam memilih sampel dengan memberikan kesempatan yang sama kepada semua anggota populasi untuk ditetapkan sebagai anggota sampel. Penentuan sampel dihitung berdasarkan tabel penentuan jumlah sampel dari populasi tertentu yangdikembangkan dari Isaac dan Michael dengan tingkat kesalahan $5 \%$ dan didapatkan sampel sebanyak 161 sampel. 
Tabel 1.

Populasi Penelitian

Data Siswa Aktif SMA Muhammadiyah 1 Palangkaraya 2017

\begin{tabular}{|c|c|c|c|c|}
\hline No. & Kelas & $\begin{array}{l}\text { Laki- } \\
\text { Laki }\end{array}$ & Perempuan & Total \\
\hline 1. & $\begin{array}{l}X- \\
\text { A1 }\end{array}$ & 14 & 20 & 34 \\
\hline 2. & $\begin{array}{l}X- \\
\text { A2 }\end{array}$ & 14 & 20 & 34 \\
\hline 3. & $X-S 1$ & 12 & 10 & 22 \\
\hline 4. & $X-S 2$ & 11 & 11 & 22 \\
\hline 5. & $\begin{array}{c}\mathrm{XI}- \\
\mathrm{A} 1\end{array}$ & 8 & 16 & 24 \\
\hline 6. & $\begin{array}{c}\mathrm{XI}- \\
\mathrm{A} 2\end{array}$ & 10 & 14 & 24 \\
\hline 7. & $\begin{array}{c}\text { XI - } \\
\text { S1 }\end{array}$ & 16 & 9 & 25 \\
\hline 8. & $\begin{array}{c}\text { XII - } \\
\text { A1 }\end{array}$ & 12 & 17 & 31 \\
\hline 9. & $\begin{array}{c}\text { XII - } \\
\text { A2 }\end{array}$ & 8 & 22 & 30 \\
\hline 10. & $\begin{array}{c}\text { XII - } \\
\text { A3 }\end{array}$ & 8 & 22 & 30 \\
\hline 11. & $\begin{array}{l}\text { XII - } \\
\text { S1 }\end{array}$ & 13 & 8 & 21 \\
\hline 12. & $\begin{array}{c}\text { XII - } \\
\text { S2 }\end{array}$ & 11 & 10 & 21 \\
\hline \multicolumn{2}{|c|}{ Jumlah } & 137 & 179 & 316 \\
\hline
\end{tabular}

Sumber Data: Data Sekunder (Data dan Statistik SMAM)

Pengambilan sampel ini menggunakan teknik Simple Random sampling, yaitu suatu tipe sampling probabilitas, dimana peneliti dalam memilih sampel dengan memberikan kesempatan yang sama kepada semua anggota populasi untuk ditetapkan sebagai anggota sampel. Pengambilan sampel penelitian dihitung berdasarkan tabel penentuan jumlah sampel dari populasi tertentu yang dikembangkan dari Isaac dan Michael dengan tingkat kesalahan 5\%.

Berdasarkan tabel Isaac dan Michael (1981:193) peneliti melakukan penghitungan penentuan jumlah sampel terhadap jumlah populasi antara 10-100000 dan sesuai dengan jumlah populasi peneliti dalam penelitian ini yaitu sebanyak 316 maka ukuran sampel yang diambil dengan taraf kesalahan 5\% adalah sebanyak 161 sampel. (Pengambilan ukuran sampel berdasarkan tabel penentuan jumlah sampel dari Isaac dan Michael).

Dengan demikian sampel yang diambil dalam penelitian ini adalah sebanyak 161 siswa. Berdasarkan perhitungan tersebut, sampel pada penelitian ini berjumlah 161 siswa dan kemudian diproporsionalkan pada masing-masing program studi pada Fakultas Ilmu Pendidikan di Universitas Negeri Semarang sebagaimana tabel berikut:

Tabel 2. Sampel Penelitian

\begin{tabular}{|c|c|c|c|}
\hline No. & Kelas & $\begin{array}{l}\text { Jumlah } \\
\text { Populasi }\end{array}$ & $\begin{array}{c}\text { Sampel } \\
\text { Proporsional }\end{array}$ \\
\hline 1. & X - A1 & 34 & $\begin{array}{c}34 / 316 \times 161= \\
17,3=17\end{array}$ \\
\hline 2. & $\mathrm{X}-\mathrm{A} 2$ & 34 & $\begin{array}{c}34 / 316 \times 161= \\
17,3=17\end{array}$ \\
\hline 3. & $X-S 1$ & 22 & $\begin{array}{c}22 / 316 \times 161= \\
11,2=11\end{array}$ \\
\hline 4. & & 22 & $\begin{array}{c}22 / 316 \times 161= \\
11,2=11\end{array}$ \\
\hline 5. & $\begin{array}{l}\mathrm{XI}- \\
\mathrm{A} 1\end{array}$ & 24 & $\begin{array}{c}24 / 316 \times 161= \\
12,2=12\end{array}$ \\
\hline 6. & $\begin{array}{l}\mathrm{XI}- \\
\mathrm{A} 2\end{array}$ & 24 & $\begin{array}{c}24 / 316 \times 161= \\
12,2=12\end{array}$ \\
\hline 7. & XI - S1 & 25 & $\begin{array}{c}25 / 316 \times 161= \\
12,7=13\end{array}$ \\
\hline 8. & $\begin{array}{l}\mathrm{XII}- \\
\mathrm{A} 1\end{array}$ & 31 & $\begin{array}{c}31 / 316 \times 161= \\
15,7=16\end{array}$ \\
\hline 9. & $\begin{array}{l}\text { XII - } \\
\text { A2 }\end{array}$ & 30 & $\begin{array}{c}30 / 316 \times 161= \\
15,2=15\end{array}$ \\
\hline 10. & $\begin{array}{l}\text { XII - } \\
\text { A3 }\end{array}$ & 30 & $\begin{array}{c}30 / 316 \times 161= \\
15,2=15\end{array}$ \\
\hline 11. & $\begin{array}{l}\text { XII - } \\
\text { S1 }\end{array}$ & 21 & $\begin{array}{c}21 / 316 \times 161= \\
10,6=11\end{array}$ \\
\hline 12. & $\begin{array}{l}\mathrm{XII}- \\
\mathrm{S} 2\end{array}$ & 21 & $\begin{array}{c}21 / 316 \times 161= \\
10,6=11\end{array}$ \\
\hline
\end{tabular}

Jumlah

316

161

Sumber Data : Primer Diolah (2018)

Instrumen yang digunakan dalam penelitian ini yaitu instrumen yang 
dikembangkan oleh peneliti dari teori yang mana indikator instrumen terdiri dari sikap berwirausaha, pengetahuan kewirausahaan, dan minat berwirausaha. Instrumen berjumlah 20 item dengan indikator pengetahuan kewirausahaan berjumlah 10 item valid dengan cronbach alpha reliabilitas $(0,862>0,70)$. Minat berwirausaha berisi 5 item valid dengan cronbach alpha reliabilitas $(0,752>0,70)$. Sikap berwirausaha berisi 5 item valid denngan cronbach alpha reliabilitas $(0,752>0,70)$.

\section{HASIL DAN PEMBAHASAN}

Berdasarkan hasil data statistik deskriptif didapat hasil bahwa pengetahuan kewirausahaan yang diukur menggunakan instrumen pengetahuan kewirausahaan secara keseluruhan memiliki skor $(\mathrm{M}=33,04$; $\mathrm{SD}=5,52$ ), sikap berwirausaha memiliki skor keseluruhan $(M=15,22 ; S D=3,31)$, dan minat berwirausaha memiliki skor keseluruhan $(\mathrm{M}=16,2 ; \mathrm{SD}=2,73)$.

Dari hasil analisis juga di peroleh nilai minimum dan maksimum. Nilai minimum merupakan nilai terendah untuk setiap variabel dan nilai maksimum merupakan nilai tertinggi untuk setiap variabel dalam penelitian. Nilai minimum untuk pengetahuan kewirausahaan adalah 15 dan maksimum 45. Sikap berwirausaha memperoleh nilai minimum sebesar 5 dan maksimum sebesar 25. Sedangkan minat berwirausaha memperoleh nilai minimum yaitu sebesar 9 dan maksimum sebesar 23 .

Selanjutnya Berdasarkan hasil selanjutnya sebagai hasil total effect (outcomeY / Sikap Berwirausaha) dapat diketahui bahwa pengetahuan kewirausahaan dengan sikap berwirausaha berpengaruh signifikan. Variabel pengetahuan kewirausahaan berpengaruh signifikan dengan sikap berwirausaha dapat dijelaskan dengan $(\beta=0,4753 ; \mathrm{t}(160)=1288,4$; dan $\mathrm{p}<$ $0,01)$. Dengan membaca hasil $\beta=0,4753$, mempunyai makna bahwa pengetahuan kewirausahaan memiliki pengaruh keduanya positif terhadap minat berwirausaha $4,7 \%$.

Untuk merangkum hasil olah data penelitian, berikut disajikan pada gambar tentang hasil olah data dan pengaruh antar variabel yang muncul pada jalur 1 yakni outcome $\mathrm{M}$ dan jalur 2 yakni outcome $\mathrm{Y}$ serta outcome outcome Y total effect.

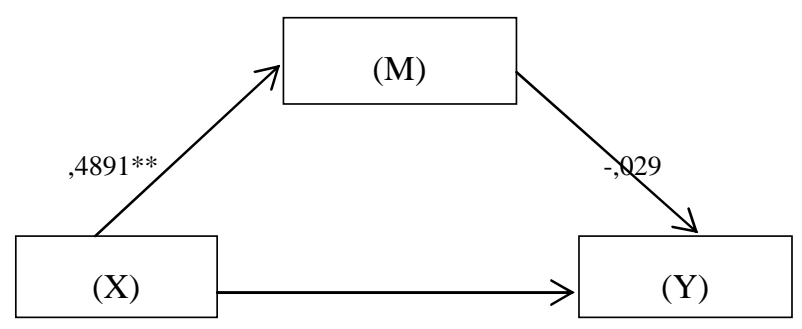

$$
, 4753^{* *}
$$

Gambar 2. Hasil Statistical Diagram $*$ signifikansi $\mathrm{p}<0,05 ; * *$ signifikansi $\mathrm{p}<$ 0,$01 ; \mathrm{N} 161$

Pada hasil analisis menunjukkan hasil uji variabel mediator menggunakan teknik bias corrected bootstrap method $\mathrm{N}=5000$. Dari hasil bootstrapping, diperoleh estimasi true indirect effect dengan level 95\%. Dengan membaca hasil di atas dapat diketahui bahwa ada pengaruh signifikan antara variabel $\mathrm{X}$ terhadap $\mathrm{M}$ dan variabel $\mathrm{X}$ terhadap Y. Namun dapat diketahui pula bahwa tidak ada pengaruh antara variabel $\mathrm{M}$ terhadap variabel $\mathrm{Y}$.

\section{KESIMPULAN}

Pada simpulan ini hasil akhir yang dapat disimpulkan adalah bahwa hasil penelitian menunjukkan bahwa pengetahuan kewirausahaan melalui minat berwirausaha secara keseluruhan berpengaruh signifikan terhadap sikap berwirausaha siswa SMA 
Muhammadiyah 1 Palangkaraya, dan minat berwirausaha tidak terbukti berpengaruh signifikan terhadap pengetahuan kewirausahaan siswa SMA Muhammadiyah 1 Palangkaraya.

Disarankan agar bisa menambah sampel maupun variabel lain yang berkaitan dengan pengetahuan kewirausahaan baik variabel independen, dependen, mediator, ataupun penambahan variabel moderator, agar hasil dapat menjadi perbandingan bagi penelitian lanjutan.

\section{DAFTAR PUSTAKA}

Cahyaning, P. 2014. Pengaruh Sikap Mandiri Dan Pengaruh Teman Sebaya Terhadap Minat Berwirausaha Pada Mahasiswa Program Studi Pendidikan Akuntansi Angkatan $2011 \quad$ Muhamadiah Surakarta. Diakses Dari Https://Putrielvinacahyaning.Wordpres s .Com/

Creswell, J. 2015. Riset Pendidikan. Pustaka Pelajar: Yogyakarta.

Hendrawan, Josia Sanchaya. 2017. Pengaruh Sikap Mandiri, Motivasi, Pengetahuan Kewirausahaan Terhadap Minat Berwirausaha (Studi Kasus Pada Mahasiswa Feb Uksw Konsentrasi Kewirausahaan). Ajie - Asian Journal

Of Innovation And Entrepreneurship (E-Issn: 2477- 0574 ; P-Issn: 24773824) Vol. 02, No. 03, September 2017.

Wahyudiono. Andhika. 2016. Pengaruh Pendidikan Kewirausahaan, Pengalaman Berwirausaha, Dan Jenis Kelamin Terhadap Sikap Berwirausaha Pada Mahasiswa Fakultas Ekonomi Universitas Muhammadiyah Surabaya. Jurnal Ekonomi Pendidikan Dan Kewirausahaan. Vol. 4. No. 1, Tahun 2016.
Wahyudin, Agus, Dr. M.Si. 2015. Metodologi Penelitian, Penelitian Bisnis \& Pendidikan. Edisi 1. UNNES Press. Semarang. 